polarographic cancer diagnosis is being successfully applied also in the Institute of Organic Chemistry (director, Prof. E. Waldschmidt-Leitz) and in the Gynæcological Clinic (director, Prof. H. Knaus), of the German University, Prague, and at several hospitals in Czechoslovakia and in Germany.

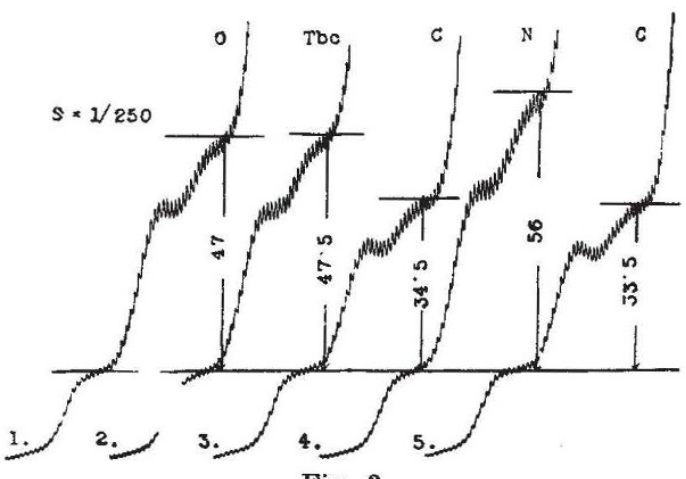

Fig. 3.

PATHOLOGICAL SERA COMPARED WITH NORMAL SERUM AFTER TREATMENT WITH PEPSIN. CURVES 1-5 REFER to the same cases as in Fig. 2.

General experience shows that the first reaction (with pepsin) deviates the more from normal the more developed is the stage of cancer-increasing from 3 to 50 per cent. An attempt is being made to refine this polarographic diagnosis by experi- menting on animals so as to distinguish an early stage of cancer. Whilst there are many details still to be investigated in the polarographic reaction of cancer, the diagnosis, just as it is presented here, offers already substantial advantages over biological tests. It is automatically registered and perfectly reproducible; the chemical treatment is very simple and comparatively short (one hour standing at room temperature); only 0.5 c.c. of serum is needed, but the reaction may even be carried out with one or two drops $(0 \cdot 1$ c.c.) of blood.

1 Brdiěka, R., NATURE, 139, 330 (1937).

2 Brdiðka, R., NATURe, 139, 1020 (1937).

'Bergh, F., Henriques, O. M., Schousboe, J., NATURE, 141, 751 (1938)。

- Heyrovský, J., and Shikata, M., Rec. Trav. Chim. Pays-Bas, 46, 498 (1925).

'Heyrovskł, J., "Polarographie", in W. Böttger's "Physikalische Methoden der analytichen Chemie", 2, 260-322 (Akad. Verlag, Leipzig, 1936).

- Heyrovský, J., "Practical Applications of the Polarographic Method in Chemistry" (in Czech) (Praha, 1933). Enlarged Russian in Chemition (Leningrad, 1837).

${ }^{7}$ Heyrovský, J., and Babixka, J., Collection of Czechoslovak Chemical Communications, 2,370 (1930); Chem. News, 141, 369, 385 (1930).

8 Brdieka, R., Collection of Czechoslovak Chemical Communications, 5, 112 (1933).

- Brdirka, R., Collection of Czechoslovak Chemical Communications, 5, 148 (1933); Biochem. Z., 272, 104 (1934).

10 Brdicka, R., Collection of Crechoslovak Chemical Communications, 5, 238 (1933); Mikrochemie, 15, 167 (1934).

${ }^{11}$ Purr, A., and Russel, M., Z. physiol. Chem., 228, 198 (1934).

${ }^{12}$ Waldschmidt-Leitz, E., Angew. Chem., 51, 916 (1936) ; WaldschmidtLeitz, E., Conrath, O., and Gloeditsch, J.,Naturwis8., 25, 60 (1937).

13 Brdicka, R., Unio Internationalis contra cancrum, Acta, 3, No. 1, 13 (Louvain, 1938). Medizin. Klinik, 33, 1186 (1937); J. Chim. Phys., 35, 89 (1938); C. R. Soc. Biol., 128, 54 (1938).

\title{
Excavations at Njoro, Kenya
}

\author{
By Dr. L. S. B. Leakey
}

$\mathrm{D}$ URING the latter part of April and the beginning of May, preliminary excavations were carried out at a small rock-shelter in the forest near Njoro, Kenya Colony, and as a result, a new branch of the local neolithic stone-bowl culture was discovered presenting certain interesting features. This small rock-shelter had been used during the neolithic period not as a living site but as a place for disposal of the dead by incineration, and the particular method which was used in burning the bodies resulted in the preservation of a number of objects not usually found in stone-age sites, owing to their perishable nature.

The method in which incineration was carried out was to dig a shallow hole in the floor of the shelter, place the body in this, in a contracted position, together with a variety of grave goods, cover the whole with soil and red ochre and then light a large fire on top. The result of this treatment was that the bodies were baked rather than burnt, while combustible objects such as baskets, cord, woodwork and even calabashes were preserved as charcoal instead of turning to ash.
As each successive body was brought to the site to be incinerated a fresh hole was dug into the charred remains of previous burnings which were then disturbed, and in course of time the deposit forming the floor of the shelter to a depth of about three feet became composed to a large extent of charcoal and burnt bone. Only the bones of the last few bodies incinerated in the shelter before it was abandoned were, therefore, reasonably intact, and the vast majority of the skulls and skeletons were much broken up.

Although only a very small part of the cave floor has been excavated, the site had been so extensively used that the remains of more than seventy individuals were recovered. Indeed, at one point, an area of one cubic yard contained the remains of sixteen individuals.

So far as can be stated at present, the human remains indicate that the population was very similar to that which I have described in the "Stone Age Races of Kenya" as the Elmenteitan type of man; but certain other elements appear to be present also. 
The human remains, however, are by no means the most interesting of the discoveries at this site, and the chief interest centres around the charred basketry and woodwork and also the many stone beads which were found.

Three quite distinct types of basket work were recovered, as well as fragments of a narrow strip of finely woven string fabric which suggest a belt. All of these were preserved as charcoal dust, but treatment with 'Durofix' dissolved in amyl acetate proved to be a satisfactory preservative, and the charcoal dust was transformed into a fairly hard substance. Large quantities of plaited fibre string and cord were also recovered in the same way.

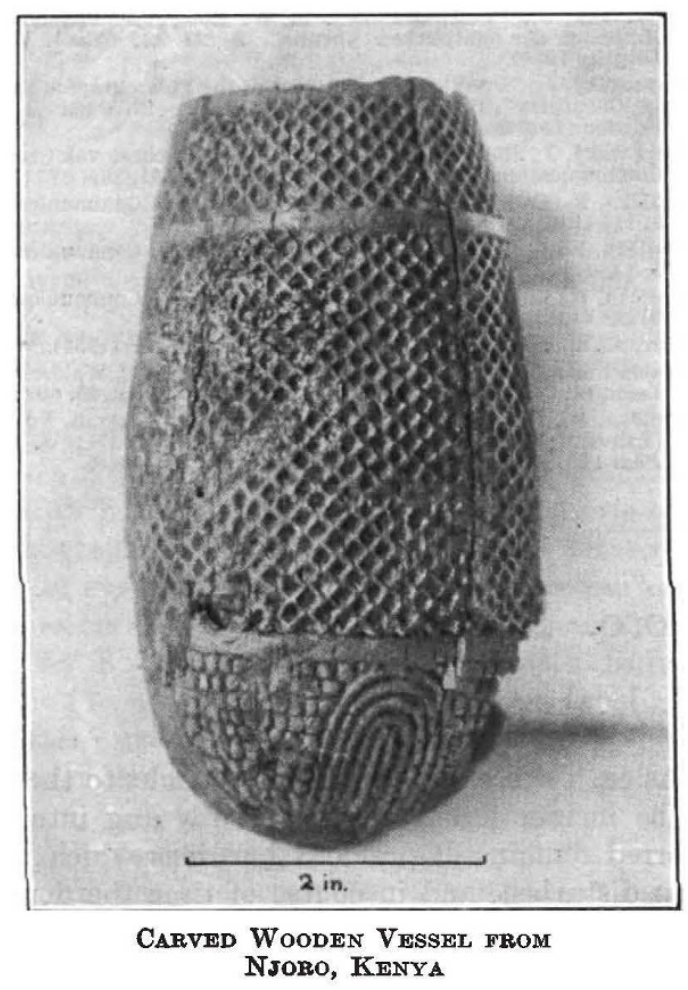

A remarkably well-carved wooden drinking vessel was found, and this is shown in the accompanying illustration. Both the detail of the carving and the finish on the inside of the vessel suggest that it could scarcely have been made by neolithic man using only obsidian tools, and we are inclined to the belief that this vessel represents an object imported from one of the early civilizations.

While the evidence of the wooden vessel alone would be insufficient ground for postulating a trade with Kenya from one of the early civilizations, this idea is strongly supported by the stone beads. Some five hundred of these as well as a number of beautiful stone pendants were recovered, and they all exhibit a very high degree of workman. ship. The semi-precious stones include fire-opals, carnelians, agates (banded and moss varieties) common opals, green quartz and Amazon stone (microcline-felspar). Of these, opals account for more than half the beads. The Amazon stone is of unusually fine quality and at first was mistaken for jade, to which it bears a superficial resemblance.

A variety of shapes of beads occur, including barrels and flat disks, the latter mainly of opal. In all cases the degree of skill shown in shaping and drilling the stone beads and the pendants contrasts strongly with that exhibited in the manufacture of the bone beads and pendants, which were certainly made by the neolithic people concerned, and this again seems to suggest that the former were made by people of superior skill and knowledge.

This view is strengthened by the fact that extensive prehistoric opal mines are connected with this site and in the surrounding area; it is difficult to believe that they were the work of neolithic man for the sake of his personal adorn. ment without a stimulus from outside.

On the evidence at present available, therefore, we incline to the view that there was influence from one of the early civilizations which initiated the mining for opals. It is even possible that there was direct contact with the traders, who employed as labour the neolithic inhabitants of the district and paid for the labour with stone beads and pendants.

Besides the articles described above, the site yielded a very large number of stone bowls and pestles of a type quite distinct from those belonging to the other branches of the local stone-bowl culture complex, a number of flat grindstones and rubbers, some pottery and also some obsidian implements. No trace of metal was found.

It is impossible at present to give a precise date to these new discoveries, but certain indications, such as the method of disposal of the dead, the physical type represented by the skulls and the nature of the obsidian tools all give a definite link with the Elmenteitan mesolithic culture. On the other hand, the stone bowls and pestles are definitely related to those found with other variants of the stone-bowl culture, but they are somewhat cruder typologically.

These facts seem to suggest a date intermediate between the mesolithic and the other neolithic industries previously discovered, and a very tentative date of circa 4000-3000 B.c. is therefore suggested.

Much will depend on whether the stone beads and pendants and the carved wooden vessel can be definitely linked with any of the early civilizations of the Near East or elsewhere. Any evidence which readers of NATURE can offer bearing on the subject would be greatly appreciated. 